\title{
De onthulling van seksueel geweld
}

\section{Book Title:}

Child sexual abuse,

disclosure, delay and denial

Book Cover:

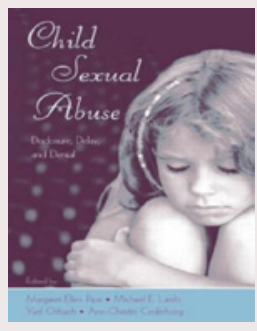

Editors:

Margaret-Ellen Pipe, Michael

E. Lamb, Yael Orbach \&

Ann-Christin Cederborg

ISBN:

0805852840

Publisher:

Lawrence Erlbaum

Associates, London, 2007, p

$301, \$ 38.25 *$

*Book price at time of Review

Review Title:

De onthulling van seksueel

geweld

Reviewer:

Tiny van der Schaaf ${ }^{1}$

Affiliation:

${ }^{1}$ Faculty of Theology,

University of Pretoria,

South Africa

Email:

tsvanderschaaf@gmail.com

Postal address:

Faculty of Theology,

University of Pretoria,

Pretoria 0002, South Africa

How to cite this book

review:

Van der Schaaf, T., 2011

'De onthulling van seksueel geweld', HTS Teologiese

Studies/Theological Studies

67(3), Art. \#1143, 1 page.

doi:10.4102/hts.v67i3.1143

(C) 2011. The Authors.

Licensee: AOSIS

OpenJournals. This work

is licensed under the

Creative Commons

Attribution License.
Dit boek is een verhandeling over de onthulling van seksueel geweld. De twee kernvragen die met betrekking tot dit onderwerp worden behandeld zijn:

- Wanneer een verdacht slachtoffer in een interview ontkent dat hij of zij misbruikt is, hoe is dan met zekerheid vast te stellen dat het kind niet misbruikt is of dat het eenvoudig weg weigert om het te onthullen?

- Wanneer een kind naar buiten komt met het verhaal van misbruik, hoe is dan met zekerheid vast te stellen dat het kind de waarheid spreekt (p. 5)?

In een poging deze vragen te beantwoorden is het boek opgedeeld in drie delen. Het eerste inleidende deel wordt een historisch overzicht gegeven van de onderliggende controversie en de bestaande literatuur betreffende onthulling van seksueel geweld (pp. 1-62). Deze bestaande onderzoeken bevatten geen informatie over hoe de kinderen geïnterviewd werden en in hoeverre protocollen gebruikt werden (p. 33). Vervolgens worden er in het tweede deel, door middel van recentere onderzoeken, nieuwe data en gezichtspunten aangeboden aangaande wanneer en waarom kinderen erin falen om het misbruik te onthullen (pp. 63-217). Tot slot wordt er in het derde deel een overzicht gegeven van de klinische, juridische en politieke implicaties met betrekking tot het onderzoek naar waarom kinderen wel en niet misbruik onthullen (pp. 219-301).

Elk deel van dit boek bestaat uit verschillende artikelen, geschreven door verschillende auteurs, bijna allemaal gebaseerd op kwantitatief empirisch onderzoek. Deze kwantitatieve onderzoeken beslaan een groot gedeelte van het boek. Het is moeilik om in te schatten in hoeverre deze onderzoeken betrouwbaar zijn. De reden daarvoor is dat wanneer een kind ontkent dat het seksueel misbruikt wordt, het niet met volle zekerheid vast te stellen is, dat het kind daadwerkelijk niet misbruikt wordt. Daarnaast zijn er ook kinderen die zeggen dat ze misbruikt zijn, terwijl dit niet het geval is. De auteurs van dit boek zijn zich bewust van dit probleem (p. 10). De auteurs richten zich daarom op het onderzoeken naar de oorzaken waarom kinderen niet naar buiten komen met hun verhaal (pp. 159-171; 251-261). Daarnaast wordt er gekeken naar de invloed van de manier van interviewen van de kinderen (pp. 135-153). Hoewel er een verscheidenheid aan oorzaken gegeven wordt waarom kinderen niet over misbruik willen praten (p. 166), is het opvallend dat geloof en kerk volledig buiten beschouwing worden gelaten. Zeker wanneer het gaat om gevallen van seksueel misbruik binnen een gelovig gezin. Daar spelen bijbelse opvattingen en godsbeelden vaak een grote rol in het stilhouden van het misbruik.

Kortom, het boek is gericht op het psychologische vakgebied en geeft handvaten voor de klinische en juridische weg daar waar gewerkt wordt met kinderen die slachtoffer zijn gemaakt van seksueel geweld of van wie vermoed wordt dat ze slachtoffer zijn gemaakt. 